\title{
Archiwa zapisów życia: czym i gdzie są?
}

Sidonie Smith, Julia Watson

TEKSTY DRUGIE 2018, NR 6, S. 174-199

DOI: $10.18318 /$ td.2018.6.14

Sidonie Smith

- profesor na Uniwersytecie Michigan.

Opublikowała m.in.:

A Poetics of Women's

Autobiography (1987)

Subjectivity, Identity,

and the Body (1993),

and Moving Lives: Wo-

men's Twentieth-Cen-

tury Travel Narratives

(2001).

i w początkach XXI wieku. Jako badaczki zapisów życia (life writing), zwracałyśmy szczególną uwagę na indywidualne lub grupowe autoprezentacje jako akty wyrażające podmiotowość, dyskutujące identyfikacje i wiążące samozrozumienie w poszczególnych gatunkach i możliwych sposobach ekspresji. Badacze/badaczki zainteresowani biografiami kobiet zajmują się innym tematem, a więc mają inne nastawienie do pisarstwa autobiograficznego. Krytycy natomiast starają się zidentyfikować źródła i różnego rodzaju materiały dotyczące życia danej osoby, łącznie z potwierdzeniem pracy nad autobiografią. To, co łączy dwa różne obszary - badania nad autobiografiami i biografiami - to zainteresowanie i uwaga poświęcona różnego rodzaju archiwom. W istocie badacze/ badaczki feministycznych zapisów życia i feministyczne biografistki spędzili dekady poszukując autobiograficznych tekstów kobiet - mało znanych lub ukrytych w rodzinnych i zbiorowych archiwach. Z kolei badacze/ rytowana profesor studiów komparatystycznych na Ohio State University. Ostatnio zajmuje się kobiecymi dziennikami wizualnymi i dorobkiem Philippe'a Lejeune'a.

Autorki książek Reading Autobiography: A Guide for Interpreting Life Narratives (2001; 2010) i Life Writing w Long Run: A Smith \& Watson Autobiography Studies Reader (2016).
Julia Watson - eme- 
badaczki zapisów życia kobiet kolorowych i członków innych mniejszości często poszukują fragmentów opisów doświadczeń w niepublikowanych rękopisach i różnego rodzaju dokumentacji.

Praca zarówno badaczy/badaczek pisarstwa autobiograficznego i biografów/biografistek życia kobiet zależy od materiałów archiwalnych. Jednak nawet prywatne dokumenty i zarchiwizowane artefakty nie są bezpośrednimi dowodami życia. Oznacza to, że materiały archiwalne nie są transparentnymi nośnikami prawdy o życiu, którą można po prostu zrekonstruować, a raczej bywają niejasne i wymagają interpretacji. Pokazują część życia danej osoby, w zależności od organizacji i celu archiwum, ale są w pewien sposób sztuczne. Chociaż instytucje takie jak publiczne repozytoria, archiwa, muzea i biblioteki umożliwiają odtworzenie, kompletowane i upamiętnienie osobistych historii, to jednak są wybiórcze - zbierają pamiątki życia w konkretnych momentach i kontekstach historycznych ${ }^{1}$, więc mogą nie dawać wiedzy o życiu niektórych osób. Co więcej, ważnym procesom historycznym, takim jak zmiany ustroju, mogą towarzyszyć realizowane na dużą skalę projekty zapominania lub wymazywania historii ludzkich.

Ponadto, archiwiści zbierają i organizują materiały przez pryzmat ideologii, które odtwarzają identyfikacje związane z płcią kulturową (gendered identities) i normy panujące w czasie ich ustanowienia i później. Normy przypisywane płci dyktują tematykę, którą uznaje się za wartą upamiętnienia i rozstrzygają, jakie osoby są wykluczane i pomijane przez wzgląd na ich identyfikację płciową, ale także rasę, przynależność etniczną lub status klasowy oraz role społeczne lub niewidoczność w społeczeństwie. Często ze źródeł pozostają tylko fragmenty jako niejednoznaczne elementy nieznanego i pomijanego życia.

Tak więc, badaczom pozostaje praca na często fragmentarycznych autozapisach i opracowanie metod dochodzenia do prawdy, które znajdują zastosowanie w kolekcjach archiwalnych, szczególnie jeśli chodzi o prace autobiograficzne. W tym rozumieniu naukowcy stają się nie tylko czytelnikami czy kompilatorami, ale także detektywami, którzy muszą kwestionować sposób w jaki źródła są „uporządkowane” i proponować wiele różnych sposobów czytania zarchiwizowanych materiałów opisujących „życie”. Dla

1 Zob. ważna praca Jacques'a Derridy Gorq̨czka Archiwów: impresja freudowska, Wydawnictwo IBL PAN, Warszawa 2016 - zawiera zgrabną analizę powiązań procesów psychicznych pamięci i technik zapisu pamięci, aktualną analizę mediów społecznościowych po roku 2000 i ich wpływ na projekty, znaczenie i różnice potrzeb między archiwami i praktyką archiwizacji i przechowywania. 
nas, teoretyków pisarstwa autobiograficznego, teksty zawierające autozapisy życia, publikowane czy nie, całościowe lub fragmentaryczne, są obiektami badań. Ani zapisy życia badanej osoby, ani zasób archiwalny nie są transparentnymi, spójnymi zjawiskami, które generują „prawdę”.

Ponieważ narracje autobiograficzne są przejawami subiektywnej prawdy, historie doświadczeń, które opisują mogą być sprzeczne, częściowe, dotyczyć różnych momentów życia i są zawsze niekompletne. Jak zauważa Joan W. Scott „doświadczenie jest zawsze jednocześnie interpretacją i potrzebuje interpretacji” ${ }^{2}$. To znaczy, że to co nazywamy „doświadczeniem” jest zawsze zapośredniczone jako zmieniający się i prowizoryczny zestaw postulatów, percepcji, uczuć i ucieleśnionych wspomnień, które zmieniają się w czasie wraz ze zmieniającym się położeniem podmiotu.

Wiele książek i esejów naszego wspaniałego kolegi, Philippa Lejeune'a, dotyczy związków między problemami teoretyki pisarstwa autobiograficznego i wyzwaniami badań archiwalnych. Często skupia się on na pamiętnikach - niepublikowanych czy o wyczerpanych nakładach - które stanowiły wyzwanie dla jego głównego projektu, śledzącego transhistoryczne zapiski osobiste we Francji w wielu zapomnianych źródłach. Lejeune napisał w 1993, że „codzienne zapiski pozostają we Francji w dużej mierze nieznane"3 szczególnie dlatego, że wielu krytyków twierdzi, że pamiętniki nie są literaturą. Sam podjął się przeczytania dziewięćdziesięciu sześciu pamiętników młodych dziewcząt, w większości niepublikowanych, które znalazł w zbiorach bibliotek i innych publicznych lub rodzinnych kolekcjach, a także otrzymał dzięki telefonom do stacji radiowych i ogłoszeniom w prasie. W istocie Lejeune stworzył swoje własne archiwum podejmując problem, jak takie pamiętniki powinny być czytane i omawiane, gdy ich XIX-wieczne „autorki były cenzurowane zarówno ideologicznie, jak i estetycznie". W ten sposób pokazał działalność teoretyków pisarstwa osobistego i pracę historyków w formalnych i nieformalnych archiwach, jako wzajemnie się uzupełniające - a nie przeciwne sobie aktywności. To wzór dla innych badaczy/badaczek.

2 J.W. Scott Experience, w: Feminists Theorize the Political, ed. by J. Butler, J.W. Scott, Routledge, New York 1992, s. 37. kin, J. Rak, trans. K. Durnin Honolulu, Center for Biographical Research, University of Hawai'i, 2009, s. 141. 
Jako nasz wkład do tej rozbudowanej dyskusji o teorii autobiografii i pracy nad archiwami historycznymi, chcemy skupić się nad tym, w jaki sposób piszący o życiu włączają materiały archiwalne z prywatnych a także formalnych zbiorów w swoje akty autozapisu. Niektórzy pisarze mogą czerpać z własnej pamięci, z jej złożonością fenomenów psychicznych, wpływów kulturowych i ucieleśnionych afektów. Mogą także korzystać z archiwów rodzinnych, które zawierają takie przedmioty jak albumy fotograficzne, genealogie, listy, różnego rodzaju przedmioty, dokumenty urzędowe, rejestry, opisy wizji, spisy przeczytanych książek lub imiona i daty zapisane w rodzinnych egzemplarzach Biblii. Inni autorzy autobiografii mogą używać materiałów z publicznych archiwów, a obecnie także ze zbiorów zdigitalizowanych, takich jak dokumenty biurokracji dawnej władzy kolonialnej, państwowej czy imperialnej, a ze zinstytucjonalizowanych archiwów - rozległe rejestry religijne i opisy przypadków medycznych.

Innymi słowy, piszący stają się czytelnikami, interpretującymi i kuratorami materiałów archiwalnych różnego rodzaju - od intymnych zapisków do anonimów. Sięgają oni także do swoich osobistych archiwów - własnych zapisów w dziennikach i pamiętnikach, przedstawień swojej osoby na fotografiach i rysunkach. W pewnym sensie piszący interpretują archiwum swoich wcześniejszych autozapisów w aktach ponownego umiejscowienia i uporządkowania przeszłości. Kiedy w ten sposób powstaje zapis życia, spotyka się on z innymi rodzajami archiwów i może być zmieniany w kolejnych edycjach lub poprzez tłumaczenie na inne języki i media. To znaczy, czytając ponownie odbiorcy otrzymują dostęp do innych wersji „życia” w czasie, tekst uzyskuje „drugie życie”, które zmienia jego relację do materiału archiwalnego.

W kolejnej części rozwiniemy tę kwestię skupiając się na wyzwaniach teoretycznych i metodologicznych. Przedstawimy osiem mikrostudiów, które zajmują się zupełnie różnymi tekstami autobiograficznymi, przede wszystkim kobiecymi, powstałymi w ciągu ostatnich czterech stuleci. Wskażemy, jaki materiał obejmuje archiwum piszącego o życiu - w przechowywanych dokumentach i przedmiotach oraz poza nimi, łącznie z subiektywnymi zapisami ucieleśnionego życia, które może być pełne sprzecznych doświadczeń i stanowisk. W międzyczasie kładziemy nacisk na następujące kluczowe pojęcia używane w krytyce zapisów życia: identyfikacja, autentyczność, otoczenie paratekstualne i pośrednictwo. Staramy się wsłuchać, co piszący o sobie samych mówią nam o materiałach, które ich dotyczą. W podsumowaniu stawiamy pytania o wyzwania badaczy/badaczek zajmujących się życiem kobiet. 


\section{Założenia wstępne}

Na początku krótko streścimy nasze podejście do zapisów życia.

1. Tekst autobiograficzny nie jest przezroczystym oknem na podmiot piszący, ale aktem interpretacji podmiotów piszących. W Reading Autobiography [Czytając autobiografie] ${ }^{5}$ zauważamy, że „zapisy życia, poprzez wspomnienia jakie budują, są zawsze zapisami aktów interpretacji w czasie historycznym i w relacji do ich własnej, ciągle zmieniającej się przeszłości. Dalej zauważamy że "teksty autobiograficzne nie są przezroczystym „oknem” na życie autora z krwi i kości. Są raczej długotrwałymi aktami autorefleksji w czasie, dokonywanej przez podmioty, które definiują swoje miejsce w rodzinie, genealogii, społeczeństwie i momencie historycznym poprzez akty zapisu w warstwach narracji, która może zawierać tekst, fotografie, rysunki itd.". Osadzone w kulturach i materiałach pisarskich, akty i praktyki autobiograficzne obejmują zjawiska wykraczające poza ramy jednego przedmiotu, poza pojedynczy tekst jako stały punkt odniesienia.

2. Każde „ja” w autobiografii jest złożone.

Podmiot w zapisie życia jest autobiograficznym „ja”. W dodatku to „ja” jest w istocie wieloma ,ja" z różnymi relacjami względem siebie i względem czytelnika. W rozdziale 3 "Reading autobiography" zaproponowałyśmy schemat, jak zrozumieć te liczne „ja”. Jest wśród nich oczywiście autor z krwi i kości, historyczna osoba, której życie jest przedmiotem opowieści. Ale czytelnicy nie mają dostępu do tego pierwszoosobowego podmiotu, tylko do jego interpretacji historii, której doświadczył.

"Ja" będące narratorem tekstu jest natomiast dostępne dla czytelników lub widzów. W zapisie autobiograficznym jest to pośrednik, kształtujący, wymyślający i opowiadający historię, lub wyznający, lub medytujący o przeszłości, lub śpiewający tekst. "Ja" narratora nie musi być pojedyncze - może zawierać wiele różnych ,ja” stworzonych w czasie, jak zdarza się w zbiorach listów lub tomach seryjnej pracy autobiograficznej.

Istnieje także „ja" będące przedmiotem narracji, czyli wersja lub wersje przeszłego samego siebie, które „ja” pamięta, wyobraża sobie, rekonstruuje, szkicuje lub odgrywa. W końcu, jest jeszcze ideologicznie „ja”, które przejawia się w tekście. "Ja" ideologicznie odnosi się do

5 S. Smith, J. Watson Reading Autobiography: A Guide for Interpreting Life Narratives, wydanie 2, University of Minnesota Press, Minneapolis 2010, s. 30.

6 Tamże, s. 71-79. 
historycznie uwarunkowanych koncepcji tego, kim jest dana osoba, która może być przedmiotem pisania o życiu i której historia jest zrozumiała lub ważna. Wszystkie te różne „ja” wprowadzają odmienne akty pamięci, wyobraźni, konstytuowania i dokonywania autoprezentacji. 3. „Ja" nie jest stałe, ale może zmieniać swój punkt odniesienia i perspektywę opowiadania. Musimy także pamiętać, że zaimek „ja”, używany podczas tworzenia opowieści o życiu, jest językowym pośrednikiem. To „ja” może czasami zmieniać się w tekście. Czasami takim pośrednikiem może być imię własne, gdzie indziej - używana jest druga lub trzecia osoba („ty" lub „ona”). W narracjach angażujących wiele osób w proces tworzenia i być może także redagowania, w przypadku współautorstwa zapisu życia, narrator jest kolektywnym „my”, zbiorem narratorów zmieszanym z różnych pozycji opowiadania.

Mając na uwadze te zastrzeżenia, przechodzimy do naszych ośmiu mikrostudiów.

\section{Mikrostudium 1: pamiętnik dzieciństwa jako źródło autentyczne}

Zacznijmy od pamiętnika dziecka. Forma pamiętnika jest często uznawana za najbardziej transparentny gatunek autobiograficzny, intymny, niewygładzony, codzienny rejestr życia. Dla badacza przeczesującego archiwa w poszukiwaniu śladów życia kobiet, pamiętnik wydawałby się wyjątkowo cennym znaleziskiem, obiecującym bezpośrednie spojrzenie na przeszłość podmiotu. Jednak, jak sugerujemy w tym studium, wartość archiwalna nawet pamiętnika dziecka wymaga szczegółowego badania, ponieważ jego transparentność może być pozorna.

Wśród rzezi wojny w Bośni i Hercegowinie na początku lat 9o., młoda dziewczyna o pochodzeniu bośniacko-chorwackim, mieszkająca w Sarajewie, kosmopolitycznej stolicy Bośni i Hercegowiny, prowadziła pamiętnik codziennego życia pod oblężeniem przez paramilitarne oddziały bośniackich Serbów, opisując bombardowania i śmierć, ale także próby prowadzenia życia towarzyskiego przez spotkania rodzinne i w szkole. Po dwóch latach kronikowania przemocy i przymusu, Zlata Filipović pokazała swój pamiętnik nauczycielce, która znalazła wydawcę w Sarajewie; dziennik ukazał się w 1993 roku po chorwacku, pod tytułem Dziennik Zlaty ${ }^{7}$, został opublikowany pod

7 Polskie wydanie nosi tytuł Dziennik Zlaty, Wydawnictwa Artystyczne i Filmowe, Warszawa1994 [przyp. tłum]. 
auspicjami UNICEF. Międzynarodowi dziennikarze, chcąc pokazać ludzką twarz oblężenia Sarajewa i wywołać większe poruszenie odbiorców na Zachodzie, odnosili się w swoich reportażach do intymnego, wzruszającego pamiętnika dziecka; wkrótce młoda Zlata stała się znaną twarzą cierpiących, określaną jako „druga Anna Frank”. Pamiętnik został przywieziony do Paryża przez francuskiego fotografa, gdzie znalazł wydawcę (Robert Laffont-Fixot), który opublikował przekład jako Journal de Zlata. Następnie pamiętnik, poszerzony o kolejne wpisy w ciągu następnych miesięcy, został opublikowany przez Viking Penguin w Stanach Zjednoczonych w 1994 roku. Jako Zlata's Diary zawitał nawet do amerykańskich szkół średnich. Zlata stała się sławnym świadkiem i dziecięcym rzecznikiem Zjednoczonych Narodów, dając świadectwo o życiu i śmierci, oblężonego dzieciństwa w czasie wojny.

Dziennik Zlaty wydawał się starannym zapisem pamiętnika nastolatki dokumentującego życie codzienne podczas wojny w Bośni i Hercegowinie, wyjątkowego przykładu przemocy etnicznej i nacjonalistycznej w historii powszechnej.W tym sensie, służy on jako źródło pokazujące świadectwo etnicznego cierpienia i wyjątkową dziecięcą wrażliwość. Jednak Dziennik Zlaty budzi pewne wątpliwości związane bezpośrednią autentycznością archiwaliów i ich reprezentatywnością. W innym eseju $u^{8}$ Sidonie Smith dokładnie analizuje opublikowany pamiętnik, tutaj wymienimy dwie jego cechy, które stanowią wyzwanie dla jego autentyczności i reprezentatywności.

Po pierwsze: autopozycjonowanie się Zlaty w swoim dzienniku jako „Anne Frank” i marketingu sławnej dziewczynki jako „bośniackiej Anny Frank”. W treści dziennika Zlata przywołuje postać Anny Frank, nadaje swojemu pamiętnikowi imię i zwraca się do pamiętnika tak jak do przyjaciółki - tak jak robiła to Anne Frank. Co więcej, gdy pierwsza część pamiętnika została opublikowana i Zlata stała się znana, w późniejszych wpisach przyjęła pozycję dziecka-świadka straconego dzieciństwa. W ten sposób patrzy na siebie poprzez figurę Anne Frank i łączy siebie z wcześniejszą ofiarą etnicznego ludobójstwa, przez co zwiększa ładunek emocjonalny pamiętnika wiążąc go z wcześniejszym dziennikiem, który już od ponad półwiecza jest obecny w świadomości czytelników na świecie? . Uznanie Zlaty za sławną przez

8 Zob. S. Smith Narratives and Rights: Zlata's Diary and the Circulation of Stories of Suffering Ethnicity, ",Women's Studies Quarterly" Spring/Summer 2006 no. 34.1 \& 2, s. 133-152. Specjalne wydanie zatytułowane Intymne i Globalne.

9 Pierwsze polskie wydanie, tłumaczone z jęz. niemieckiego ukazało się w 1957 roku w Warszawie nakładem PIW. 
dziennikarzy i marketing jej dziennika w ramach współczesnego porządku praw człowieka ma podwójny efekt - podnosi autentyczność głosu (sentymentalizowanego) dziecka i nadaje temu przekazowi charakteru uniwersalnego poprzez jego komodyfikację w globalnym obiegu narracji świadków. Paradoksalnie jednak samoświadoma performatywność pamiętnika podważa przejrzystość efektu prawdy niewinnego świadka-dziecka i „patrzenia oczami dziecka".

Po drugie - kwestia autentyczności zapisu cierpienia dziecka, które zostaje ujawnione jako sztuczny efekt komodyfikacji. Wydania pamiętnika opublikowane poza Bośnią zawierały sugestywne fotografie. Jedno ze zdjęć pokazujące Zlatę w łóżku, opatrzone było podpisem „Zlata, miłośniczka książek, czyta przy świetle świec”. Jednak, jak zauważył recenzent z „Newsweeka”"10, fotograf, aby zrobić to zdjęcie musiał użyć lampy błyskowej, a w ten sposób światło flesza niweczy autentyczność zdjęcia dziecka przy świecach. Nie sugerujemy, że dziennik dziewczynki, zawierający archiwum codziennego cierpienia podczas ludobójczej wojny jest „nieautentyczny” jako świadectwo świadka, ale zauważamy, że w tym przypadku źródło autobiograficzne nie jest tylko prywatnym artefaktem, ale także efektem dyskursu o prawach międzynarodowych, figury dziecka w pamięci światowej i złożonych procesów produkcji, obiegu i odbioru osobistego świadectwa komodyfikowanego przez światowe rynki.

Ten przykład pokazuje jak trudne problemy napotykamy, gdy opublikowany dziennik wchodzi do międzynarodowego obiegu i odbiór zmienia go, podobnie jak autora w przedmiot konsumpcji. Możemy myśleć o tym procesie jako sprzężeniu zwrotnym, ponieważ pamiętnik dziecięcego doświadczenia przemocy jest zależny od archiwum zapisów w dzienniku i materiałów związanych z życiem w ukryciu innej dziewczynki. Gdy to "podobieństwo” wkracza do obiegu, autorka pamiętnika rozumie samą siebie przez jego pryzmat.

\section{Mikrostudium 2: archiwa publiczne i postpamięć}

W tej części chciałybyśmy pokazać jak twórcy świadomi swojej niepewnej pozycji ofiar historii, radzą sobie z problemami autentyczności materiałów archiwalnych i publikacji. Dokumentując swoje historie o wrażliwości korzystają z wielu publicznych i osobistych archiwów, które razem tworzą wartość tego świadectwa. Także w takich przypadkach mogą pojawić się wątpliwości. 
Przykładem są wspomnienia w formie komiksu Arta Spiegelmana, Maus. Opowieść ocalatego ${ }^{11}$,odnoszące się do licznych publicznych i rodzinnych źródeł umiejscawiających historię rodziny w historii kolektywnej, w „punkcie, gdzie zderza się Historia świata i Historia osobista"12. Stworzona przez Spiegelmana osoba mówiąca - Art - jest jednocześnie wytrwałym badaczem i narratorem niewiarygodnym, ale dokumentacja do której się odnosi jest wiarygodna. Maus zawiera wiele rodzajów formalnych i nieformalnych materiałów archiwalnych dotyczących powstawania powieści. Przede wszystkim jest transkrypcja nagrania indywidualnej historii ojca (Vladka) jako mit o sobie samym, ta historia jest zestawiona z mniej pochlebną biografią ojca opowiedzianą przez syna, „Arta-Narratora” i opowieścią Arta-artysty o tym jak stworzył komiks ${ }^{13}$.

Dodatkowo, Spiegelman włącza dokumenty z archiwum rodzinnego. Są wśród nich krótkie życiorysy kilku członków rodziny, którzy zostali zabici lub zmarli w wyniku samobójstwa podczas Holokaustu, a których Spiegelman nigdy nie poznał. Przy tablicach genealogicznych, fotografiach, rysunkach i opowieściach nawiązuje do historii kolejnych pokoleń rodzin ojca i matki w Polsce. Z archiwów publicznych Spiegelman zaczerpnął fakty dotyczące europejskich Żydów, razem z mapami, planem komór gazowych i składem używanego w nim cyklonu B; cytaty z książek i gazet pokazują jak szeroko rozpowszechniona była ideologia faszystowska i przekonanie o wyższości rasy aryjskiej. Spiegelman opisuje szczegóły wizyty Arta w Auschwitz i źródła do jakich miał tam dostęp. Ta olbrzymia dokumentacja jest włączona w narrację poprzez rysunki, które czytelnicy mogą zweryfikować w innych miejscach, autor zebrał je później jako materiał najpierw w aplikacji HyperCard, CD-ROMie, następnie w tomie MetaMaus ${ }^{14}$. W Maus Spiegelman wplata także wcześniejszy osobisty pamiętnik w formie komiksu „Więzień piekielnej planety", w którym młody Art jest pokazany jako nieszczęśliwy nastolatek z obsesją na punkcie samego siebie. Nawiązuje także do historii, które nie mogą zostać opowiedziane albo dlatego, że brakuje dowodów, albo łączą się z ogromnym bólem - tak jak samobójstwo matki Arta, do którego doszło, gdy

Polskie wydanie: A. Spiegelman Maus - opowieść ocalałego. Część pierwsza - Mój ojciec krwawi historiq, Post, Kraków, 2001.

A. Spiegelman W cieniu nieistniejq̨cych wież, Wydawnictwo Komiksowe, Warszawa, 2018. 
był nastolatkiem. W ten sposób luki - to, co w źródłach jest niedostępne lub zbyt bolesne do opowiedzenia - także tworzą część historii.

Co ważne, użycie źródeł historycznych w Maus jest „historią zwykłych ludzi": jego relacja o Holokauście to historia opowiadana z punktu widzenia ofiar, pokazuje najazd na Polskę, próby ukrywania się przed okupantem i kolaborację niektórych Polaków, aresztowania i transporty do obozów śmierci, świadectwa życia w nich z opisami metod eksterminacji, oraz następstwa wojny - walkę o przeżycie w ukryciu, w obozach dla uchodźców i wyzwania życia na wygnaniu (w wypadku rodziny Spiegelmana - w Szwecji), i emigrację do Nowego Jorku. Jednak ta ponura dokumentacja jest przedstawiona w formie interesujących komiksowych rysunków, a historie opowiadane są przez postacie przedstawione jako zwierzęta. Spiegelman ryzykuje użycie komiksu, aby dotrzeć do czytelników, którzy mogą być niezainteresowani historiami ofiar Holokaustu.

Zatem w Maus Spiegelman umieszcza swojego narratora, Arta, w co najmniej trzech rolach - jako urażonego syna, „surowego" artystę komiksowego i zaradnego badacza, który czerpie z wielu archiwów po części dlatego, że jako dziecko urodzone po II wojnie światowej, nie ma bezpośrednich wspomnień odnośnie do doświadczeń swojej rodziny. Badaczka Marianne Hirsch takie związki z przeszłością nazywa „postpamięcią"15 Opisała jak korzystał z niej Spiegelman. Jak pisze Hirsch, „postpamięć” opisuje relację drugiego pokolenia wobec osobistej, zbiorowej i kulturowej traumy, której doświadczyli poprzednicy - wobec przeżyć, które „pamiętają” tylko poprzez historie, obrazy i zachowania, wśród których dorastali. Jednak te doświadczenia zostały im przekazane tak głęboko i z taką dozą emocji, że wydają się stanowić ich własne wspomnienia ${ }^{16}$. Jak sugeruje Hirsch, postpamięć określa pośrednią relację do przeszłości - „pośrednią... przez zaangażowanie wyobraźni, projekcję i kreację"17.

Ponieważ komiksy Spiegelmana powstały z pozycji postpamięci, a nie pamięci bezpośredniej, nie mogą być transparentnym opisem. Nawet dokumenty archiwalne, do których autor się odnosi są narysowane, a więc zinterpretowane i znarratywizowane. Jak pokazuje praktyka Spiegelmana z Maus,

Zob. M. Hirsch Family Pictures: Maus, Mourning and Post-Memory, "Discourse" Winter 1992-1993 no. 15.2: s. 3-29; tejże The Generation of Postmemory: Writing and Visual Culture After the Holocaust, Columbia University Press, New York 2012. 
nie jest możliwe transparentne przekazanie danych archiwalnych o wcześniejszych wydarzeniach, gdy badacz znajduje się poza nimi. Musi zdecydować, jaki kształt nadać historii, jaką wagę nadać różniącym się i sprzecznym rodzajom dowodów, oraz czy pokazać spójną historię, czy podkreślić napięcia a nawet sprzeczności, które mogą ją rozbijać, ale i czynić bardziej wymowną.

\section{Mikrostudium 3: archiwa uczuć i impresji}

Czy zadanie pisarza/pisarki jest inne, jeśli jest naocznym świadkiem wydarzeń, o których pisze? Jak pokazał przypadek Dziennika Zlaty, relacje takich świadków łączą się z problemami - zdobywaniem wiary czytelnika i potwierdzeniem „prawdy” narracji. Spiegelman włączył wiele różnych materiałów w swój komiks, aby uwierzytelnić swoją prawdę opowieści o doświadczeniach zarówno ofiar jak i ocalałych, które opierały się na osobistych i publicznych archiwach - „obiektywne” dowody w postaci zdjęć i dokumentów dotyczących wydarzeń historycznych lub miejsc. Jest jeszcze inny rodzaj osobistego archiwum, także dostępny dla pisarzy - archiwa uczuć. Mają one ważne miejsce w kobiecym pisarstwie o życiu.

Ann Cvetkovich, w An Archive of Feelings, uznaje argument Derridy o nieosiągalności archiwalnej prawdy, ponieważ wszystkie archiwa są miejscami „walk o wiedzę i władzę"18.

Jednak opiera się na wielu rodzajach źródeł, szczególnie z archiwów gejów i lesbijek, takich materiałach jak filmy dokumentalne i codzienna „historia mówiona, osobiste zdjęcia i listy oraz efemerydy", aby argumentować istnienie archiwum uczuć, określane przez nią jako "praktykę fantazmatyczną", która koncentruje się na emocjach i uczuciach ${ }^{19}$.

Według Cvetkovich nawet opublikowane narracje mogą być uznane za „impresje"20 a nie obiektywne zapisy, bo sugerują jak pamięć jest tworzona, nawet przez naocznych świadków.

Rozważmy następujący przykład. Na początku XX wieku, urodzona w Chicago Mary Borden, mimo że była dziedziczką fortuny i matką trojga małych

18 A. Cvetkovich, An Archive of Feelings: Trauma, Sexuality, and Lesbian Pubic Cultures, Durham, NC: Duke University Press, Durham, NC 2003, s. 268.

Tamże, s. 269. 
dzieci, zgłosiła się jako ochotniczka do pracy pielęgniarki podczas I wojny światowej. Przez cztery lata pracowała w belgijskiej i francuskiej części zachodniego frontu. The Forbidden Zone: A Nurse's Impressions of the First World War [Zakazana strefa: Impresje pielęgniarki o I wojnie światowej] to kolekcja siedemnastu krótkich impresji z dramatyzowanymi opisami jej doświadczeń jako pielęgniarki szpitalnej ${ }^{21}$. Inaczej niż w znanych opowieściach, jak $\mathrm{Na}$ Zachodzie bez zmian Ericha Marii Remarque'a i Testament of Youth [Testament Młodości] Very Brittain ${ }^{22}$, Borden swoją historię ułożyła w serię impresji zapamiętanych momentów z jej służby, wiele z nich w urywkach pisała w szpitalach. Chociaż Borden próbowała opublikować je już w 1917 roku, Forbiden Zone uznano za zbyt kontrowersyjne i nie ukazało się do 1929 roku, gdy zaczęły pojawiać się nieocenzurowane relacje o I wojnie światowejej3. Sama Borden określiła swoje zapiski jako nielinearną „kolekcję fragmentów”, którą krytycy uznali za „brzydką” i pełną powtórzeń. Jednak ponieważ jej archiwum pokazuje wspomnienia jako odczuwane impresje, powtórzenia w szkicach dobrze oddają zamieszanie i absurdalność momentów na froncie, poprzez przedstawienie surowych i surrealistycznych perspektyw ${ }^{24}$.

Na przykład w Bombardment [Bombardowanie] w ciągu trzech stron narracja przechodzi od pojawienia się drobiny „podróżującej wysoko przez tajemniczy zmierzch" i "wirującego silnika" ${ }^{25}$ do powolnego przebudzenia miasta i „przerażenia i oszołomienia"26, następnie widoku z lotu ptaka „blizny pojawiły się na nim jak ślady ospy” $i$ „rany pojawiły się na jego ulicach”27. Po tym jak samolot „roześmiał się” w mieście, a następnie zniknął w słońcu, „miasto pozostało drżące”28. W tym spojrzeniu z lotu ptaka na zniszczenia bombardowania, Borden pozostaje niewidoczna. Faktograficzny zapis ofiar bombardowania zamieniony jest na sensualną narrację o zniszczeniu przez

21 M. Borden The Forbidden Zone: A Nurse's Impressions of the First World War, seria Hesperus Modern Voices, Hesperus Press, London 2008. E.M. Remarque Na zachodzie bez zmian, wiele wydań; V. Brittain, Testament of Youth: An Autobiographical Study of the Years 1900-1925, Macmillan, London 1934.

H. Hutchinson Introduction, w: M. Borden The Forbidden Zone, s. xiv.

Tamże, s. xv.

M. Borden The Forbidden Zone, s. 11.

Tamże, s. 12.

Tamże, s. 13.

Tamże, s. 13. 
wojnę zarówno zaatakowanych terenów jak i uczestniczących żołnierzy. Takie krótkie „impresje” pokazują destrukcyjność i przewrotność tej wojny. Malcolm Brown, historyk z Imperialnego Muzeum Wojny w Londynie, uznał tekst Borden za arcydzieło i „znaczący wkład w literaturę tego konfliktu" z jego ciętą, ale pełną współczucia narracją o wydarzeniach z punktu widzenia pielęgniarki na froncie ${ }^{29}$. A zatem zredagowanie przez Borden swoich naprędce spisanych szkiców łączy jej osobiste archiwum z ważnymi wydarzeniami historii powszechnej i tworzy archiwum uczuć, które zarówno wzbogaca jak i podaje w wątpliwość relacje w oficjalnych archiwach.

Archiwum uczuć może także zakłócić logiczną ciągłość narracyjną w niektórych narracjach o życiu, takich jak historia udanej migracji i asymilacji. Mary Antin, która wyemigrowała z rosyjskiego sztetla do Stanów Zjednoczonych pod koniec XIX wieku, opublikowała The Promised Land: The Autobiography of a Russian Immigrant $t^{30} \mathrm{w} 1912$ roku jako opowieść o amerykanizacji, w której młoda kobieta opowiada o swoim doświadczeniu. Zapewnia, że jej historia jest reprezentatywna, napisana w czasach napastliwych antyimigranckich dyskursów w debatach o „obcych” i zagrożeniu dla narodu przez outsiderów w Ameryce na początku XX wieku.

Historia Antin, w stylu opowieści o nawróceniu, opowiada zamysł i proces stawania się posłuszną amerykańską obywatelką a także przy okazji uwypukla radykalny brak ciągłości między starym światem Europy Wschodniej a nowym w Ameryce. Podczas gdy pierwsza część tekstu opowiada o jej dzieciństwie $\mathrm{w}$ rosyjskim sztetlu, pokazywanym jako zacofany w swoim średniowiecznym podejściu do kobiecości; druga część to Bildungsroman, opowieść o edukacji formalnej i o domu dla imigrantów (settlement house). W tej opowieści wzorowy uczeń staje się „Amerykaninem” poprzez akt woli. Autorka kultywuje i eksponuje pożądane cechy przedsiębiorczej ambicji, indywidualizmu w duchu Emersona i nowoczesną kobiecość.

Jednak niektóre fragmenty w The Promised Land zakłócają historię o asymilacji Antin. Kiedy narratorka, już po przemianie w obywatelkę amerykańską, przywołuje swoje dzieciństwo w Połocku, odkrywa, że jej dziecięce „ja” jest dla niej niemal całkowicie stracone. To, co potrafi przywołać, to wspomnienia o zapachach jedzenia i węchowe doznania podczas jedzenia, szczególnie

M. Brown Forward, w: M. Borden, The Forbidden Zone, s. xi. 
sernika jej matki: „Dlaczego mogę nawet przez pół godziny marzyć o nieśmiertelnym smaku tych dużych serników, które jadaliśmy w sobotnie wieczory" ${ }^{\text {"31 }}$. Wspomnienie sernika prowadzi do długiego opisu wrażeń zmysłowych ucieleśnionego przywiązania, ten zapis wrażeń spowalnia narrację o amerykanizacji i zakłóca opis żydowskiej strefy osiedlenia w Imperium Rosyjskim jako opresyjnej. Korzystając z osobistego archiwum uczuć, Antin pokazuje, w jaki sposób archiwa osobistych wspomnień ukazują sprzeczności, ambiwalencje i paradoksy zapisów życia w przypadku autorów, którzy migrują do innego narodu, kultury i historii. Narratorka identyfikuje się jako zasymilowana Amerykanka, a jednak pisze o tęsknocie do utraconej przeszłości, mimo że określa ją jako poniżającą. Paradoksalnie, pamięta o tym, co powinno być zapomniane, aby asymilacja „zadziałała”.

Przeformułowane wspomnienia jako archiwa uczuć w tego rodzaju narracjach o życiu nie mają autorytetu oficjalnych historii, ale są ważnym subiektywnym „dowodem” dla większych, publicznych wydarzeń, w których brali udział ich narratorzy. Wzajemne przenikanie się odczuwanej subiektywności i wydarzeń historii światowej, takich jak wojna i masowa migracja, pokazuje zindywidualizowaną, mniej homogeniczną interpretację doświadczenia historycznej zmiany.

\section{Mikrostudium 4: archiwa dopisanej przeszłości}

Wspomnienia o przeszłości nagle pojawiające się w opowieści o imigracji Antin mogą być ciekawym tematem dla piszącego o życiu. Na przykład autorzy pamiętników często czytają na nowo swoje wcześniejsze wpisy i mogą je reinterpretować na marginesach, szczególnie w niepublikowanych tekstach. Twórcy listów podobnie - po przemyśleniu mogą nie zgadzać się ze swoimi wcześniejszymi poglądami. Piszący memuary - mogą dołączać zdjęcia swoje, rodziny, przyjaciół, które podważają tekst lub każą spojrzeć na przeszłość tych osób w inny sposób. Podsumowując prace niektórych piszących o życiu zawierają zapisy wcześniejszych wersji ich samych, co pokazuje ich jako dynamicznych i zmieniających się.

Przykładem pisarstwa autobiograficznego, które pokazuje wyraźne zmiany w tożsamości autora, jest Memories of a Catholic Girlhood autorstwa Mary McCarthy ${ }^{32}$. Mimo że te wspomnienia zdają się być chronologiczną nar-

31

Tamże, s. 90-91.

M. McCarthy Memories of a Catholic Girlhood, Harcourt, Brace, New York 1957. 
racją o jej młodości czerpiącą z esejów, które pisała przez ponad dekadę, poszczególne rozdziały są opatrzone refleksjami napisanymi, gdy redagowała książkę, a które podają w wątpliwość jej wcześniejsze wspomnienia i historie o sobie samej.

To znaczy, że McCarthy wyraźnie pokazuje, że jej wizja samej siebie zależy od momentu lub punktu widzenia, z którego patrzy na swoją przeszłość. Na przykład jeden z rozdziałów opisuje ścisłą kontrolę babki nad nią i jej bratem, gdy jako osierocone dzieci dorastali w domu, w którym rządziła jako „centrum władzy" ${ }^{\prime 33}$. Natomiast w komentarzu na końcu rozdziału McCarthy zastanawia się: „w pewnym sensie byłam niesprawiedliwa wobec mojej babci. Pokazuję ją z perspektywy czasu, patrząc na nią i oceniając ją jako dorosła. Ale jako dziecko lubiłam ją, uważałam ją za niesamowitą postać. Wiele jej wad - np. mrożący krew w żyłach katolicyzm - wtedy za wady nie uważałam" ${ }^{\text {34 }}$. W komentarzu do innej historii umieściła bardziej ogólną uwagę: „jest tu kilka pół-fikcyjnych akcentów... Uporządkowałam rzeczywiste wydarzenia tak, aby stworzyć z nich «dobrą historię». Trudno pokonać tę pokusę, jeśli ma się zwyczaj pisania fikcji”" W ${ }^{\prime 2}$ ten sposób wspomnienia McCarthy są kontekstualizowane jako subiektywne „wrażenia”, nawet jeśli ich autorytet dla tej chwili jest potwierdzony.

Nowszy przykład pojawia się w pracy współczesnej artystki queer Alison Bechdel, której graficzne wspomnienia są zatytułowane Fun Home. Tragikomiks rodzinny ${ }^{36}$. Jej narratorskie „ja” to starsza artystka czytająca na nowo i zastanawiająca się nad swoją przeszłością, zarówno w relacji do historii jej rodziny, jak i historii homoseksualizmu w XX-wiecznej Ameryce. Graficzne wspomnienia przedstawiają dorastanie w Pensylwanii, w rodzinie, która prowadzi dom pogrzebowy [oryginalny tytuł zawiera grę słów Fun Home to wesoły dom, ale też nawiązanie do funeral home - dom pogrzebowy przyp. tłum.] i składa się z grupy autystycznych artystów, którzy traktują swój dom jako ,artystyczną komunę"37. Jednym z wątków Fun Home jest odkrywanie przez córkę, Alison, swojej tożsamości jako artystki-graficzki i lesbijki. Musi ona także jako 17-latka skonfrontować się ze śmiercią ojca w wieku 44

Tamże, s. 34 .

Tamże, s. 50.

Tamże, s 164-165.

W Polsce ukazały się w 2009 roku w Warszawie nakładem wydawnictwa Timof i cisi wspólnicy.

A. Bechdel Fun Home, s. 134 . 
lat, prawdopodobnie w wyniku samobójstwa; i historią jego stłumionego homoseksualizmu, co ich łączyło. Fun Home, z pięknymi rysunkami i dowcipną narracją, zawiera wiele szkiców dokumentów, zarówno zapisów rodziny, jak i przedmiotów i zapisków młodej Alison, które świadczą o jego jakości materialnej, nie tylko jako dokumentacja, ale także ucieleśnienie historii Bechdel.

Warto zauważyć, że w archiwum osobistym użytym w Fun Home, są dzienniki, które rodzice poradzili pisać Alison, jako pomoc przy jej zaburzeniach nerwicowych. Chociaż codzienne zapiski jej dziennika - reprodukowane dziecięcym charakterem pisma - zawierają wiele dat i imion, samoświadomość młodej Alison wkrótce zmusza ją do pisania „tak mi się wydaje” po każdym zdaniu. Później zaczyna tworzyć skróty, oznaczając każdą percepcję symbolem, rodzajem akcentu, które bazgrze tak często, że wpisy stają się niemal nieczytelne. Dziennik staje się mniej autentyczny, gdy Alison, z powodu niestarannego pisma, dostaje polecenie dyktowania "oficjalnych" epizodów z jej życia codziennego matce. Te „oficjalne” wpisy pomijają ważne wydarzenia osobiste. Na przykład pamiętnik narracyjnego ", ja" zawiera wpis o pływaniu, ale nie wspomina nic o pierwszej miesiączce; takie intymne doświadczenia są cenzurowane w oficjalnej rodzinie. W końcu nastoletnia Alison porzuca pisanie dziennika, który Bechdel określa jako rozpoznanie swojego młodego ja „ukrytego kłamstwa pustej strony" ${ }^{\text {38 }}$.To świadczy o wtedy niewypowiadanych homoseksualnych pragnieniach, które czuł także jej ojciec, co wywarło ogromny wpływ na jej seksualność.

Jak na ironię, gdy młoda Alison przestała pisać konwencjonalny dziennik, ta porażka staje się punktem startu dla jej innowacyjnej rysunkowej autoprezentacji. Bechdel podważa wartość archiwum jej wczesnego pamiętnika jako autentycznego źródła o jej życiowych doświadczeniach i metakrytycznie odkrywa, jak czytać zwracając uwagę na luki i nadpisane momenty. Jako czytelnicy poruszamy się między kontrapunktami: opowiadanym dziennikiem "Ja" w oknach dialogowych komiksu i metakomentarzem w dopiskach dorosłej narratorki w polach powyżej, które zawierają jej aktualne spojrzenie na temat tego, co faktycznie przeżyła, pomyślała i poczuła. W ten sposób pokazuje, że luki mogą być bardziej wymowne niż to, co zapisane wprost.

W obu przytoczonych tekstach starsza narratorka podkreśla, że teraz inaczej podchodzi do samej siebie z przeszłości - jako podmiot podlegający formacji, który może być niechętny lub nie być w stanie ujawnić swojej kształtującej się wewnętrznej historii. Oba przytoczone przykłady podają 
w wątpliwość wiarygodność i autentyczność pojedynczych przykładów z prywatnych archiwów. Oba sugerują też, że nie tylko powinniśmy czytać krytycznie, ale także radzą w jaki sposób to robić.

\section{Mikrostudium 5: kolekcje jako ujednolicone archiwa}

Do tej pory w naszych przykładach skupiałyśmy się na tekstach autobiograficznych, zauważając skomplikowane relacje między autoprezentacją a archiwum tekstu, zmyślenia w archiwach, przekonania ich dotyczące i ich zawartość. W kolejnym studium przypadku zastanawiamy się nad problematyką drugiego życia aktów i praktyk autobiograficznych, a szczególnie, co dzieje się, gdy zapis trafia do archiwum i przez to uzyskuje drugie życie.

Weźmy np. drugie życie kobiecych historii w antologiach. Na Zachodzie istnieje długa tradycja tworzenia antologii dotyczących życia - od średniowiecznych zbiorów żywotów świętych po XIX-wieczne kolekcje biografii kobiet sławnych lub o określonej profesji; teksty te należą do gatunku nazwanego przez Alison Booth prozopografiąa ${ }^{39}$.W Reading Autobiography definiujemy prozopografię jako praktykę tworzenia zbiorczego studium cech dzielonych przez grupę osób, których poszczególnych biografii często nie można wyróżnić, celem jest badanie relacji i schematów w życiorysach w konkretnym momencie historycznym ${ }^{40}$. Wraz z nadejściem drugiej fali feminizmu w końcu XX wieku kolekcje osobistych historii kobiet stały się sposobem zbiorowego relacjonowania o życiu (life storytelling), łączą one aspekt osobisty i polityczny, aby potwierdzić znaczenie autorytetu doświadczenia. Pojawiło się wiele takich antologii: kolekcje o przemocy wobec dzieci, lesbijskie opowieści o coming-oucie, świadectwa kobiet kolorowych o ucisku i aktywizmie, w krajach rozwijających się historie o dekolonizacji, i inne. Pod koniec wieku, gdy pojawił się dyskurs o prawach człowieka i stworzono instytucje, gdzie zajmujące się prawami kobiet, liczne antologie świadectw kobiet maltretowanych i krzywdzonych były dostępne jako dokumentacja osobista.

Celem tych redagowanych wydawnictw było wyrażenie poparcia dla postulatów o uznanie i naprawę, nie tylko stały się archiwami, ale także ujawniły

A. Booth How to Make It as a Woman: Collective Biographical History from Victoria to the Present, University of Chicago Press, Chicago 2004. Booth pisze o prozopografii w Anglii od połowy XIX wieku do XX stulecia, gdzie publikowano tomy zestawiające historie kobiet o podobnych doświadczeniach, profesji lub statusie. 
kwestie dotyczące drugiego życia świadectw kobiet. Jak zauważają Kay Schaffer i Sidonie Smith, gdy historie kobiet są publikowane jako kolekcja, albo w trakcie życia bohaterek albo po ich śmierci, proces redakcji może tworzyć nowe konteksty, które wpływają na to, jak teksty te są czytane i jaką większą historię zamierzano danym zbiorem opowiedziećc ${ }^{41}$. Kwestie kontekstu i możliwości tworzenia archiwum stają się w ten sposób istotne. Zebranie opowieści w antologię tworzy archiwum kolektywnych doświadczeń. Często historie są ze sobą powiązane jako świadectwa jakiejś krzywdy lub osadzone w narodowym lub transnarodowym kontekście przemocy i cierpienia. Kampanie dotyczące praw człowieka z pewnością korzystają na publikacji antologii, które gromadzą archiwum świadectw wspólnych doświadczeń ofiar, szczególnie gdy są one kontekstualizowane przez uczonych-działaczy, którzy dostarczają cennych informacji historycznych i kontekstowych. Celem takich zbiorów, w druku i na stronach internetowych, jest pisanie historii na nowo, nazwanie sprawców, uznanie postulatów i inspirowanie dalszych działań. Jednak gdy chodzi o łamanie praw, a historia jednej osoby jest włożona w ramy innej - może być w wyniku tego ograniczona przez dyskurs, który tworzy ją zrozumiałą dla wybranej grupy odbiorców, reinterpretowana przez inne historie, z którymi jest zestawiona, czy tak okrojona, żeby pasowała do wymogów opowieści o przekazie budzącym emocje.

Rozważmy przykład.W 1994, Inger Agger, duńska psycholog, opublikowała The Blue Room. Trauma and Testimony among Refugee Women: A Psychosocial Exploration $^{42}$ [Niebieski pokój. Trauma i świadectwo wśród imigrantek: eksploracja psychosocjologiczna]. Agger zestawiła historie kobiet świadczące o przemocy, molestowaniu seksualnym i uwięzieniu, patrząc przez pryzmat psychologii. Tytułowy pokój jest jednocześnie fizycznym miejscem i metaforą. Dosłownie - Agger rozmawiała z kobietami, których historie zebrała w niebieskim pokoju w swoim domu, przenośnie - niebieski pokój to miejsce uzdrowienia. Podobnie jak w klasycznym pałacu pamięci, w którym zapamiętuje się kolejne elementy poruszając się w wyobraźni po pomieszczeniach budynku, rozdziały książki gromadzą świadectwa świadków w „pokojach” oznaczonych jako różne rodzaje traumatycznych przeżyć. Przechodzenie przez wspomnienia i praca nad traumą są powiązane. Książka zawiera relacje z pierwszej ręki kobiet

41 K. Schaffer, S. Smith Human Rights and Narrated Lives: The Ethics of Recognition, Palgrave Macmillan, New York 2004.

42 I. Agger The Blue Room. Trauma and Testimony among Refugee Women: A Psychosocial Exploration, Zed Books, London 1994. 
z Ameryki Łacińskiej i Bliskiego Wschodu, które żyją w Danii jako uchodźczynie i migrantki, zachodni paradygmat terapeutycznego modelu pamięci i rekonwalescencji indywidualizuje proces dochodzenia do siebie, ale jednocześnie ten proces upraszcza i uniwersalizuje jego przebieg.

Zbiory świadectw kobiet, które przeżyły radykalne okaleczenia i krzywdę, rozprzestrzeniają się jako olbrzymie archiwum opisów doświadczeń, krążące w światowym obiegu narracji o prawach człowieka. Z pewnością takie prace stanowią niezwykłe projekty dotyczące historii zwykłych ludzi (storytelling from below), opowieści o kobietach, które doświadczyły poniżenia, ucisku, marginalizacji, wykorzystania, dehumanizacji, zapomnienia i porzucenia. Jednak kolekcje te, mając duże znaczenie jako archiwalny zapis, są także pod wpływem globalnej polityki dyskursu praw człowieka, instytucji, protokołów i metod obiegu.

Historie kobiet są uwikłane w tworzenie postulatów praw człowieka i ideologie, takie jak te o naprawie i procesie leczniczym. Są one podmiotem różnego rodzaju obiegu: wymogów dostosowania wydawców szukających pokupnych historii o prześladowaniu i przetrwaniu, zaangażowania sprawców w wyparcie i zniesławienie, i nacisku na tworzenie opowieści dopasowanych do ogólnego szablonu, który najlepiej dopasowuje się do ram prawnych.

\section{Mikrostudium 6: parateksty, epiteksty i republikacja}

Paratekstowy materiał publikowanej historii o życiu zawiera wszystko, co ją otacza - dokumenty nadające mu ramy i materiał publikacji, który współtworzy jej drugie życie w kolejnych edycjach i wersjach ${ }^{43}$. Łącznie tworzą archiwum przechowywania i odbioru, które nie jest statycznym repozytorium, ale wielostronnym i zmiennym zbiorem świadectw. To znaczy, że archiwum dotyczące życia nie jest usytuowane w przeszłości podmiotu; a porusza się wraz ze zmieniającą się teraźniejszością i jest otwarte na przyszłe zmiany.

Gérard Genette nazywa to materiałem paratekstowym, który otacza historię. Materiały paratekstowe książki są dodawane podczas procesu przygotowania do publikacji - zawierają np. okładkę, wewnętrzne strony okładki, wstęp, tytuły rozdziałów i formatowanie tekstu, motto (np. na przykład w pierwszej części Maus - cytat Hitlera), dedykacja, fotografie itd. Paratekst może być zmieniany w kolejnych wydaniach książki. Epitekst natomiast stanowią materiały "otaczające" książkę powstałe już po publikacji. Mogą to być: reklamy, wywiady, recenzje itp. Genette wskazuje, że materiały paratekstowe mogą wydawać się "neutralne”, ale w rzeczywistości rzutują na odbiór i interpretację książki przez różnych czytelników. Gérard G. Genette, Paratexts: Thresholds of Interpretation, Cambridge University Press, Cambridge, New York, 1997; por. S. Smith, J. Watson Reading Autobiography..., s. 99-100. 
W naszym kolejnym przykładzie przyglądamy się, jak znacząco może zmienić się tekst historyczny w czasie dekad publikacji i odbioru.

Opowieść o uprowadzeniu Mary Rowlandson, po raz pierwszy opublikowana w 1682 roku, ma historię wydań trwającą trzy stulecia. Porównanie kilku wydań takiego tekstu pokazuje mikro- i makrozmiany w epitekście pierwszego wydania. Możemy zaobserwować, kiedy pojawiają się ilustracje, a kiedy są usuwane, zauważyć zmiany odnośnie autorów przedmowy i posłowia, rozważyć kiedy i dlaczego dołącza się aneksy. Zmiany między pierwszą publikacją a kolejnymi dotyczą także rozmiaru książki, kroju pisma, wzornictwa, jakości papieru, okładki, dokładnego tytułu i tak dalej. Kolejne edycje miały różnych wydawców, często powiązanych z różnymi społecznościami lub grupami, choć pierwsze wydanie opublikowała purytańska społeczność, do której należała Rowlandson. Republikacja przez wydawcę z innej społeczności postawiłaby Rowlandson w innym świetle. Podobnie - republikacje wydawnictw akademickich opracowujące tekst do wykorzystania naukowego. To znaczy, że różne wersje narracji o życiu przemawiają do różnych odbiorców i mają różne cele społeczne i kulturowe podczas życia drukowanego tekstu.

Historia edycji A True History of the Captivity and Restoration of Mrs. Mary Rowlandson [Prawdziwa historia uprowadzenia i uratowania pani Mary Rowlandson] w Stanach Zjednoczonych pokazuje jak skomplikowane są tamtejsze archiwa historyczne. Mogliśmy zaobserwować podobną drogę innych dzieł - np. narracja Harriet Jacobs, amerykańskiej niewolnicy, o jej życiu przed wykupieniem na wolność, czy zapis duchowej podróży po Europie spisany w średniowieczu przez Angielkę Margery Kempe po jej nawróceniu. W takich przypadkach badacze muszą starannie określić, do której drukowanej wersji tekstu się odnoszą. Często nie ma „autorytatywnej wersji”.

Badacze/badaczki starający się stworzyć kolekcję tekstów z historiami o życiu kobiet muszą dokładnie przyjrzeć się archiwom, szukając następujących informacji: dla tekstów publikowanych, kto wymyślił ich publiczność lub konsumentów w czasie, gdy były pisane i potem. Jaką rolę w obiegu narracji mają zbiorowości, takie jak grupy przyjaciół, kluby książki, biblioteki, lub - współcześnie - programy typu talk show albo blogi? Jaka była recepcja historii danej kobiety w pamiętnikach, listach i innych pamiątkach jej czytelników?

Udostępnianie materiałów archiwalnych, które rozwiązują te problemy, może dostarczyć fascynujących szczegółów na temat kulturowej reinterpretacji historii życia. Rzeczywiście, kolejne wersje historii życia powstającej w czasie ponownej publikacji są same w sobie historią. 


\section{Mikrostudium 7: archiwa i remediacja}

Jak zauważyłyśmy, archiwa zapisów życia nie są zamkniętymi zbiorami, ale obiektem odnowy i rewitalizacji poprzez nowe informacje i interpretacje, które generują kolejne wersje podmiotu. Ale dowód nie może udowadniać się sam. Spójrzmy na autobiograficzne dzieło Charlotte Salomon, niemieckiej artystki żydowskiego pochodzenia. Jej rozległy projekt obrazów z podpisami zatytułowany Życie? Czy teatr?, coraz szerzej znany wśród historyków sztuki i badaczy/badaczki Holokaustu, umieszcza historię jej rodziny w Berlinie, podczas wczesnych lat rządów nazistów. Salomon udało się na jakiś czas uciec przed prześladowaniami - wyjechała na południe Francji, gdzie z pasją malowała i pisała skomplikowaną historię życia swojej rodziny z perspektywy Nietzscheańskiej wizji życia i śmierci, której nauczył ją nauczyciel śpiewu operowego jej macochy, który był też jej kochankiem. Gdy Salomon wyszła za mąż w urzędzie w Nicei pod rządami Vichy, niestety dotarło do nich gestapo, oboje z mężem zostali aresztowani we wrześniu 1943. Ciężarna Charlotte i jej mąż zostali wysłani do Auschwitz, gdzie wkrótce zostali zamordowani. Zginęła w wieku 26 lat. Jeszcze w 1943 swoje prace oddała znajomemu lekarzowi, który przechował je i w 1947 oddał członkom rodziny, którym udało się przeżyć wojnę w Holandii.

Życie? Czy teatr? to dzieło pomyślane jako sztuka lub singspiel - gatunek przypominający operetkę; 789 obrazach namalowanych gwaszem z podpisami (dodatkowo przezroczyste nakładki z podpisami i sugerowana muzyka) opowiada problematyczną przeszłość rodziny, z ośmioma samobójstwami, w większości dotyczącymi kobiet, łącznie z matką artystki, jej ciotką i babką. Prace Salomon były wystawiane od 1961 roku. Przekazano je Żydowskiemu Muzeum Historycznemu w Amsterdamie, które zgromadziło archiwum zawierające także inne jej obrazy, zdjęcia rodzinne, listy i powiązane manuskrypty. To główne archiwum materiałów stworzonych lub dotyczących Salomon zostało rozszerzone także o tłumaczenia i wersje Życie? czy Teatr? w innych mediach: siedem filmów, opera, kilka sztuk teatralnych, biografie i powieść biograficzna, jak również wiele opracowań i katalogów wystaw, oficjalna strona internetowa i inne witryny online ${ }^{44}$. Każda z tych remediacji eksponuje inne momenty interpretując narrację wizualno-tekstową.

Oprócz dokumentu Weisz Leven of Theater? [Życie czy Teatr?] powiązanego z dramatem biograficznym Charlotte z 1981 roku, którego Weisz był współautorem scenariusza i reżyserem (to jeden z siedmiu filmów o Charlotte i jej rodzinie), należą tu także opera Charlotte Salomon francuskiego kompozytora Marc-André Dalvabie (premiera na festiwalu w Salzburgu w 2014 roku), poetycka powieść Charlotte Davida Foenkinos, świetnego francuskiego biografa, tłuma- 
Niedawno w filmie Fransa Weisza Leven of Theater? (2012) [Życie czy Teatr?] po raz pierwszy pokazano dziewiętnaście dodatkowych obrazów i list stanowiący epilog dzieła, w którym Salomon dokonuje wprost wstrząsającego wyznania o zamordowaniu swojego dziadka. Praca nad tymi nowymi materiałami, które uznać można za gorszące wyznanie, będzie wymagała nowych krytycznych interpretacji i radykalnych działań. W przypadku dzieła Salomon, to co nazywamy remediacją cały czas się toczy i ma kontrowersyjny charakter ${ }^{45}$. Burzliwe dyskusje, jakie się wywiązały, będą trwały nadal, dotyczą one nie tylko faktów z życia Salomon i interpretacji Życie? czy Teatr?, ale także kwestii, jakie znaczenie powinna mieć jej praca w badaniach nad Holokaustem. Historyczka sztuki Griselda Pollock, czołowa badaczka Salomon, argumentuje, że wręcz przeciwnie, nowe treści zawarte w liście pomagają w odczytaniu performatywności Życie? czy Teatr? ${ }^{46}$. Wskazuje na dziadka Salomon, jako źródło krzywdy, która dotknęła jej rodzinę ze strony matki ${ }^{47}$. Zatem, nawet siedemdziesiąt lat po śmierci Salomon, jej praca wciąż rodzi pytania dotyczące zarówno dowodów historycznych, jak i etyki jej projektu. Widzimy więc, że debaty dotyczące archiwów na temat pisarstwa o życiu mogą pozostać otwarte, nawet jeśli wydaje się, że wszystkie „dowody” zostały znalezione.

\section{Mikrostudium 8: archiwa cyfrowe i życie w sieci}

$\mathrm{Na}$ koniec krótko rozważmy, jaki wpływ mają media cyfrowe na nasze rozumienie tego, czym jest archiwum, a nawet życie. Wraz z eksplozją digitalizacji, do jakiej doszło w XXI wieku, i pojawieniem się projektów Big Data, materiały, które poprzednio były rozdrobnione w mało dostępnych oficjalnych

czona na kilka języków europejskich, wystawy prac Salomon w 2016 roku w Muzeum Massena w Nicei i w 2017/2018 w Żydowskim Muzeum Historycznym w Amsterdamie, oraz nowa praca Griselda Pollock, wspomniana poniżej, jak również wiele recenzji.

Zob. film Weisza z 2012 roku oraz T. Bentley The Obsessive Art and Great Confession of Charlotte Salomon, The New Yorker online (15.07.2017), artykułzawiera rozważania czy Salomon mogła być morderczynią.

46 Pollock wskazuje na oskarżenie Salomon jako odnoszące się do „faktycznego morderstwa kilku młodych kobiet przez starszego człowieka" zob. G. Pollock Charlotte Salomon and the Theater of Memory, Yale University Press, New Haven, CT 2018, s. 227.

47 Julia Watson pracuje właśnie nad retoryczną analizą długiego listu Salomon jako zapisu życia, przekonuje w niej, że [pozornie] oczywiste stwierdzenia w liście muszą być umieszczone w odpowiednim kontekście i inaczej rozumiane. 
archiwach, instytucjach i magazynach, stały się częścią cyfrowej ekologii, dotyczącej „teraźniejszości ciągle połączonej w sieć" (continuously networked present $)^{48}$, jak określił to Andrew Hoskins. Kiedy dokumenty będące poza siecią, zostają zarchiwizowane online, ich status zmienia się w zależności od architektury i stopnia interaktywności platform i systemów kodowania, a także możliwości oprogramowania i sprzętu.

Ten proces transferu prowadzi do rodzaju algorytmicznego przechowywania, które może być mniej lub bardziej dyskryminujące w swoich regułach tworzenia zbiorów. Co więcej, ponieważ koszty związane z digitalizacją archiwów są często wysokie, finansujący je mogą wpływać na to, co jest zdigitalizowane.

Do digitalizowanych archiwów dołącza się te, które powstały online, stworzone i utrzymywane przy życiu dzięki logice algorytmów, które wpływają na repozytoria Big Data. Te dane zawierają ogromne ilości informacji ściągniętych z portali social media, a wszystkie one generują miejsce do samoobrazowania (self-imaging), samopisu (self-inscription) i samoprzechowywania (self-curation). Włączamy tu także dane zgromadzone przez rządy i firmy zajmujące się bezpieczeństwem, a nawet hakerów. W tych archiwach online badacze/badaczki mogą śledzić „cyfrowe ślady” (digital footprints) i napotkać to, co Kylie Cardell nazwała "cyfrowym śmietnikiem” (digital clutter), nadmiar dostępnych dokumentów ${ }^{49}$.

Praca badaczy zależy od wcześniejszych badań, ale także programistów i architektów sieci przy rozwijaniu metadanych i wyświetlaniu architektury danych, za pomocą której można wyszukiwać i wizualizować materiały. Jak zauważył Xin Huang, „metadane uwalniają” materiały takie jak obrazy „z ich bezruchu i nadają im nową polityczną ontologię i formę sprawczości"50.

Wreszcie - trafność konkretnych wyszukiwań dotyczących źródeł historycznych, w materiałach online i Big Data, zależy od dalekowzroczności kodujących, jakości metadanych i otwartości witryny. A zatem archiwa cyfrowe, zarówno zdigitalizowane, jak i powstałe online, nasuwają wątpliwości metodologiczne i etyczne badaczy życia kobiet.

48 K. Cardell zapożycza to określenie od Andrew Hoskinsa Modern Memory-Making: Marie Kondo, Online Journaling, and the Excavation, Curation, and Control of Personal Digital Data, „a/b: Auto/ Biography Studies" 2017 no. 32:3, s. 499-517, 506. 
Chociaż nie możemy tu omówić wielu złożonych problemów związanych z gromadzeniem ogromnych internetowych archiwów osób, zauważamy pewne intrygujące zjawiska, które będą stanowić wyzwanie dla badaczy/badaczek kobiecego życia online. W tym nowym środowisku kuratorzy tworzonych przez siebie treści (self-curators) nie są w stanie kontrolować, gdzie trafiają wszystkie fragmenty ich życia w sieci - są wykorzystywane, rozpowszechniane i przechowywane w archiwach innych osób lub osierocone gdzieś w chmurze. Gdyby uznali, że nie będą w stanie podołać zadaniu uporządkowania zawartości wymykającego się spod kontroli archiwum siebie samego, pojawiły się na rynku firmy oferujące usługi agregacji. Na przykład dla tych, którzy chcą zbudować bardziej spójną tożsamość, „Uberflip” oferuje „scentralizowanie istniejących treści".To wyzwanie będzie także dotyczyć badaczy/badaczek zajmujących się treściami przechowywanymi przez osoby, których dotyczą. Bardzo możliwe są też inne wyzwania w przyszłości. Ponieważ zarówno historyczne i współczesne życie stały się tematami gier online, ludzie mogą wirtualnie „zamieszkać” w życiu innych. W związku z tym, w przyszłości, badania dotyczące archiwów osób mogą również ujawnić ich fantazje, ponieważ poprzez gry te osoby tworzą alternatywne jaźnie, stają się celebrytami o których marzą, awatarami heroicznych bohaterów. Badacze/badaczki zainteresowani opowiadaniem kobiecych opowieści napotkają wyzwania w środowisku Internetu, miejscu niewyobrażalnym dla wcześniejszych pokoleń badaczy.

\section{Podsumowanie}

Pokazałyśmy, w jaki sposób archiwum nie jest pojedynczym lub statycznym repozytorium dokumentów - dowodów historycznych, ale zbiorem dynamicznych i zmieniających się miejsc. Zastanawiałyśmy się, jak piszący o życiu czerpią zarówno z publicznych archiwów, jak i osobistych archiwów pamięci i postpamięci, w tym nie tylko z opowieści, metafor i znanych gatunków, ale też z uczuć i wrażeń. Zauważyłyśmy, że piszący o życiu mogą napotkać trudności zastanawiając się nad swoimi powiązaniami z różnymi archiwami.

Zaobserwowałyśmy też, jak drugie życie niektórych tekstów o życiu, poprzez republikację lub remediację, budzi wątpliwości związane z przebiegiem procesu twórczego, obiegu i odbioru twórczości autobiograficznej. Z naszej perspektywy jako badaczek zapisów życia, autobiograficzne prace kobiet na całym świecie dostarczają inspiracji co do podejścia do czytania archiwaliów i odkrywania ich pouczających opowieści, nawet gdy zmagamy 
się z trudnościami w dokładnym ustaleniu w nich pewnej prawdy dotyczącej podmiotu.

Z naszych rozważań wynika kilka etycznych i metodologicznych pytań dotyczących pracy nad zapisami życia kobiet i ich archiwalnymi dowodami.

- Badacze/badaczki służą jako „postarchiwalni” kolekcjonerzy, agregatorzy i kuratorzy, którzy muszą skonfrontować się z tym, jak projekty w oficjalnych i nieoficjalnych archiwach mają tendencję do kolektywizowania i homogenizowania historii ludzi w sposób, który podporządkowuje im konkretne interesy, imperatywy instytucjonalne i ramy narracyjne. W jaki sposób archiwa narzucają klasyfikowaną tożsamość historiom opartym na doświadczeniach kobiet, które redukują odczuwalne i przeżywane życie zestawu funkcji lub czynności?

- Jak naukowcy mogą wyszukiwać inne historie, ślady odczuwanego życia, w archiwum uczućs ${ }^{2}$ ?

-W jaki sposób badacze/badaczki mogą poradzić sobie z fizycznymi trudnościami związanymi z pracą archiwalną, w szczególności z częstym gromadzeniem się nieskatalogowanych materiałów? W jaki sposób mogą uzyskać dostęp do materiałów przechowywanych w archiwach rodzinnych i osobistych? (nowatorskie rozwiązanie, jakie Philippe Lejeune opisuje, może być początkiem ${ }^{52}$ ).

- Gdzie w archiwalnych fragmentach można znaleźć niedostępne materialne ciało podmiotu - kompilację jej historii, wrażeń i afektów?

- Problem usuwania niektórych osób i subiektywności z oficjalnych zapisów - jak badacze/badaczki mogą wykorzystać fragmenty na marginesach i w rejestrach?

- Kiedy podmiotowości nie można zbudować z fragmentów archiwalnych, jakie możliwości tworzenia historii są dostępne etycznie, czy przy poszanowaniu milczenia i niekompletności można znaleźć jakieś treści? Jak elokwentnie opisuje Marlene Kadar, uczeni stają się świadkami pracy polegającej na odzyskiwaniu utraconych opowieści, gdy „składają fragmenty i pozwalają im się jąkać" (The Devouring) ${ }^{53}$. Biography Studies" 2017 no. 32:3, s. 625-628. 
- Czy gdy nie można zrekonstruować życia podmiotu lub chociaż teoretyzować o podmiotowości, można sobie wyobrazić alternatywne możliwości opowiadania historii?

-I wreszcie, jakie pytania - a nie stwierdzenia - mogą pozwolić badaczom/badaczkom tchnąć życie w świadectwo archiwów jaźni?

Powołamy się jeszcze na wyzwanie Derridy dotyczące archiwów: „Pytanie o archiwum nie jest pytaniem o przeszłość. Jest to kwestia przyszłości, kwestia przyszłości samej w sobie, kwestia odpowiedzi, obietnicy i odpowiedzialności za jutro" ${ }^{54}$.

Przetożyła Dorota Boni Menezes

\section{Abstract}

\section{Sidonie Smith}

UNIVERSITY OF MICHIGAN

\section{Julia Watson}

OHIO STATE UNIVERSITY

The Archives of Those Who Write Themselves: What and Where Are They?

Smith and Watson propose eight micro-studies exploring the challenges of researching life writing. Their sources are familiar to Polish readers - Zlata's Diary by Zlata Filipović, Art Spiegelman's Maus, the writings of Mary Antin or Charlotte Salomon's autobiographical series of paintings. The authenticity of those works is examined in terms of the different perspectives of the artist, autocreation, human rights or the editing process, which gives rise to new contexts. Smith and Watson also refer to the problem of postmemory and the archive of feelings, which enrich official accounts while also questioning them. They point to issues related to digitalizing existing sources and life in the web, which creates new possibilities and challenges for both artists and researchers.

\section{Keywords}

life writing, autobiography, archive, digital archive, archival collections, digitalization of archives

54 J. Derrida Gorączka archiwum. 